\title{
Population densities and habitat associations of the range-restricted Rock Firefinch Lagonosticta sanguinodorsalis on the Jos Plateau, Nigeria
}

\author{
DAVID WRIGHT and PETER JONES
}

\section{Summary}

Population densities, using distance sampling, and habitat associations of the range-restricted Rock Firefinch Lagonosticta sanguinodorsalis were investigated between late May and early July 2002 in a protected site at Amurum on the Jos Plateau, Nigeria, and in unprotected surrounding habitats. Rock Firefinches were strongly associated with inselbergs and rocky outcrops and avoided scrub and abandoned farmland. Density was not significantly higher on the Amurum protected site (0.79 birds/ha; 95\% CL 0.51-1.21) than on the unprotected areas (0.55 birds/ha; 95\% CL 0.37-0.82). Rock Firefinches were locally common around inselbergs on the Jos Plateau, even where this habitat was unprotected. It remains uncertain to what extent increasing habitat degradation may affect this species' ability to persist as small populations in isolated habitat fragments. Rock Firefinch's host-specific brood parasite, the similarly rangerestricted Jos Plateau Indigobird Vidua maryae, was not seen until June during this study, and no density estimate is available.

\section{Introduction}

In recent years several populations of the African brood parasitic indigobirds Vidua have been recognized as distinct species (Payne 1996). One of these populations, from the Jos Plateau area of northern Nigeria, has been recognized since 1992 as the Jos Plateau Indigobird V. maryae (Payne 1994, 1996, Payne and Payne 1994). In 1995 R. B. Payne found that the Jos Plateau Indigobird was mimicking the songs of a previously unrecognized species of firefinch, Rock Firefinch Lagonosticta sanguinodorsalis (Payne 1998). The holotype of Rock Firefinch was subsequently collected at Taboru Hill in the Amurum woodlands near Jos, the state capital.

Rock Firefinch and its brood parasitic indigobird are considered range-restricted endemics of the Jos Plateau and its north and eastward extensions (Payne 1998), and are therefore of particular conservation interest and concern. However, sightings of birds thought to be Rock Firefinches have been recorded well off the plateau in the Mandara mountains in north-eastern Nigeria on the border with Cameroon (Payne 1998, Fry and Keith 2004) but their identity remains to be confirmed.

The Jos Plateau is the largest land mass in Nigeria over 1,000 $\mathrm{m}$ a.s.l., forming "an isolated vegetation unit within the Guineo-Congolian/Sudanian Regional Transition Zone" (White 1983). Despite sharing some biological affinities with the Cameroonian 
highlands, the Jos Plateau is considered geographically distinct and to warrant treatment as a separate ecoregion, the Jos Plateau Forest-Grassland Mosaic (WWF 1998). The plateau stretches from its westernmost point, at $8^{\circ} 30^{\prime} \mathrm{E}$ in the Kagoro Hills, eastwards to $9^{\circ} 30^{\prime} \mathrm{E}$ and from north to south between $10^{\circ} \mathrm{N}$ and almost $9^{\circ} \mathrm{N}$.

Much of the vegetation of the Jos Plateau has been devastated by tin-mining operations, which were at their peak during the 1920 (Hadejia et al. 2000). A high human population (200-300 people per $\mathrm{km}^{2}$ ) has resulted in continued, large-scale deforestation and conversion of grass and scrubland to agriculture. The few remaining patches of forest and woodland are being heavily depleted by the unsustainable collection of wood for fuel (Lodewijk and Were 2001). Only a few areas of natural grassland, savanna-woodland and forest remain, which are mostly confined to places with impeded access. With the exception of occasional sacred groves, the majority of trees close to settlements are those that are useful to the communities living amongst them (Lodewijk and Were 2001). One of the best remaining areas of natural vegetation on the Jos Plateau is the Amurum woodlands $15 \mathrm{~km}$ north-east of Jos (Ezealor 2001), the site at which the holotype of Rock Firefinch was collected. Amurum is characterized by sparsely vegetated inselbergs (isolated granitic hills of rounded bare rock rising abruptly from the surroundings) and rocky outcrops in dry scrub-savanna, interspersed with small patches of gallery forest. Although small (c. 90 ha; Wright 2002), this site has recently been recognized by BirdLife International as an Important Bird Area (IBA category A3, site NGo20; Fishpool and Evans 2001). The Amurum woodlands hold a significant component of the 42 species of bird whose distributions are largely or wholly confined to the Sudan-Guinea Savanna biome. Unlike the majority of Jos Plateau vegetation that remains, Amurum has not survived through inaccessibility - historically, the site was set aside for the circumcision ceremony of young men (Ajik Agwom Nyam, verbally 2002). Although this use of the land ceased many years ago, the site remains a sacred grove and, as such, has not been over-exploited for its resources by the surrounding community of Laminga. A recent project, sponsored jointly by the Nigerian Conservation Foundation, the Royal Society for the Protection of Birds, the World Wide Fund for Nature (WWF-UK) and the UK Department for International Development, has seen the site come under participatory, communitybased management. It is now regarded as an offence, by order of the Laminga Community, to fell trees, hunt, graze animals, light fires and cultivate the land. It is hoped that this project will ensure the conservation of the area, whilst developing sustainable ways of utilizing the forest resources.

This study aimed to compare the population density of Rock Firefinch at Amurum with densities in unprotected degraded habitat and to establish the species' habitat associations. Any differences in population densities could then be compared with differences in habitat availability and suggest whether habitat degradation might pose a potential threat to Rock Firefinch populations.

\section{Methods}

\section{Bird surveys}

Field data were collected by D. W. between 26 May and 9 July 2002 at four different sites on the Jos Plateau (see inset to Figure 3). Initially, work began at the protected Amurum woodlands site $\left(9^{\circ} 53^{\prime} \mathrm{N}, 8^{\circ} 59^{\prime} \mathrm{E}\right)$ and the unprotected area immediately 
surrounding it, moving later to other unprotected areas close to the communities of Laminga $\left(9^{\circ} 50^{\prime} \mathrm{N}-9^{\circ} 52^{\prime} \mathrm{N}\right.$ and $\left.8^{\circ} 59^{\prime} \mathrm{E}-9^{\circ} \mathrm{O} 1^{\prime} \mathrm{E}\right)$ and $\operatorname{Vom}\left(9^{\circ} 41^{\prime} \mathrm{N}-9^{\circ} 46^{\prime} \mathrm{N}\right.$ and $8{ }^{\circ} 41^{\prime} \mathrm{E}-$ $\left.8^{\circ} 48^{\prime} \mathrm{E}\right)$. The habitats around Laminga and Vom are typical of the Jos Plateau: a mosaic of scrub, cultivated and abandoned farmland and granitic rocky outcrops.

Birds were surveyed by distance sampling using the variable circular plot method (Reynolds et al. 1980). This method was chosen rather than linear transects because the topography and vegetation at Amurum and throughout the Jos Plateau made it impossible to (a) lay out transects without biasing the habitats sampled (Bibby et al. 2000) and (b) effectively observe birds whilst traversing a straight line. Moreover, the environment of the Jos Plateau is very patchy, comprising a mosaic of habitats. It was therefore preferable to collect habitat association data for individual birds whilst standing still (Buckland et al. 2001, Bibby et al. 2000).

At Amurum the count-points were laid out systematically as a N-S, E-W grid that extended at least $300 \mathrm{~m}$ outside the reserve boundary into the unprotected habitat. The grid was established using a GPS (Garmin 12) and points were positioned at least $100 \mathrm{~m}$ apart to ensure their independence (Bibby et al. 2000). A total of 129 points were located in Amurum with a further IOI located in unprotected habitat immediately surrounding the site. A further nine point-transects were laid out near the communities of Laminga and Vom. The length of these transects varied between approximately $1.4 \mathrm{~km}$ and $2.8 \mathrm{~km}$, depending on access and human settlement (see below) and comprised a total of 165 points. The points on each transect were located at least $100 \mathrm{~m}$ from each other. The location of each transect was chosen at random from a sample of 30 suitable sites that had to fulfil the following criteria: (I) they had to be located within a 30 min drive (or combination of driving and walking) from Jos, where D. W. was based and (2) the incidence of dwellings along the transect had to be low, because the presence of other people within the sampling area would influence the behaviour of both the observer and the birds. Placing transects in areas of lower human habitation was not thought to bias the survey, because all habitat types found within the region were represented in the point-transects.

Surveys were all carried out between o6h15 and 1ohoo. No counts were undertaken in rain, fog or strong wind, which would affect both bird activity and detectability. Each point was surveyed for 5 min (measured with a countdown timer), to reduce the potential influence of evasive movements (Scott and Ramsey 1981), and to ensure that all birds at the point itself were detected with certainty (Assumption 1 of distance sampling; Buckland et al. 2001). Time was approximately equally split between scanning the area with the naked eye and scanning with $10 \times 45$ binoculars. When approaching a point, birds flushed from the point were recorded if it was believed that they would have been at that point had the observer not caused them to flee. This ensured that birds were detected at their initial location, which is especially important for birds sighted on or near the point (Assumption 2; Buckland et al. 2001). In this case, it was the distance from the bird's original position to the point that was recorded, not the distance from the bird to the observer at the moment of sighting. If a bird took flight during a count, the distance to the take-off point was measured. However, any flying birds that were not seen taking off were not recorded, because it was not possible to ascertain their original location (Buckland et al. 2001).

All distance measurements were recorded from the point origin to the bird as exact continuous distances (not grouped), using a laser rangefinder (Leica LR4Oo) that measured distances between $10 \mathrm{~m}$ and $1,000 \mathrm{~m}$ with a precision of $\pm 1 \mathrm{~m}$. Distances 
of birds recorded less than $10 \mathrm{~m}$ from the point were measured by pacing, calibrated afterwards against a tape measure. Distances to aural cues were taken in the same way from the point origin to the suspected origin of the call. Birds were counted individually, not as groups.

\section{Calculation of population densities}

Population densities (birds/ha) and encounter rates (individuals/point) were calculated from the point-count data using the program DistANCE v.3.5, release 6 (Thomas et al. 1998). Data were post-stratified by region (Amurum versus all unprotected habitats combined) in the stratum layer and the global detection function calculated across pooled strata. Although there was a wide variety of habitat types in each stratum, it was not possible to estimate habitat-specific detection functions because too few observations were made. However, models used by Distance are "pooling robust" to variation in detection probability (Buckland et al. 2001).

Histograms of the distance data were prepared with data partitioned into 15 groups to help detect evasive movement away from the observer and consequent "heaping", and to identify outliers or data entry errors. As all measurements were made exactly, the problem of heaping was mitigated. Based on these histograms, the dataset was truncated to discard observations of the most distant birds, which may be both unreliable and difficult to model. All detection function models and adjustments were considered and the model with the lowest AIC was selected. The cut-points for distance categories were then manipulated to give the lowest chi-squared value for goodness-of-fit between the model and the data.

\section{Habitat availability}

Following each point-count, the habitat within a $15 \mathrm{~m}$ radius of the point was subjectively classified into one of eight categories: inselberg, rocky outcrop, scrub, grassland, gallery forest, riparian, farmland or disused farmland. As placement of transects was random with regard to habitat type, this was assumed to give a reliable indication of habitat availability throughout the study area. Where more than one habitat occurred at a point, it was classified into the category that occupied the largest area of the $15 \mathrm{~m}$ radius.

\section{Habitat associations}

In addition to recording the habitat around each point, the habitat in which each bird was observed was also categorized as above. Chi-squared tests $\left(\chi^{2}\right)$ were used to assess whether birds were distributed randomly with respect to habitat availability, or whether specific habitat associations were evident.

Within Amurum, GIS was used to provide graphical representation of bird observations. The major habitat types — inselberg, scrub and gallery forest - were mapped with a GPS and the data uploaded into ArcView (v. 3). The position of each bird observation was also recorded with a GPS and added to the projection. This allowed for general inferences of habitat association to be made within the site. However, as neither farmland nor abandoned farmland is represented within Amurum woodlands, the projection can only provide inference for habitats largely undisturbed by human influence. 


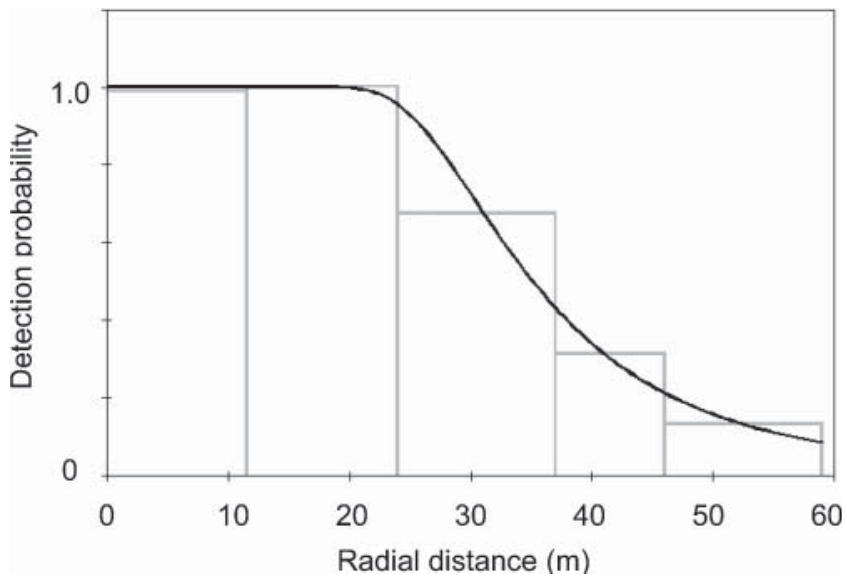

Figure 1 . Histogram of distance data and best fitting detection function (hazard-rate model) for Rock Firefinch. Goodness-of-fit $\chi^{2}=0.03$, d.f. $=2, P>0.98$.

\section{Results}

\section{Population densities and encounter rates}

A total of 129 independent observations of Rock Firefinches were made, allowing the species' detection function to be modelled accurately (Buckland et al. 2001).

Exploratory analysis of the distance data suggested the need to truncate observations at $59 \mathrm{~m}$, corresponding to the removal of 12 observations and $9.3 \%$ of the data. All detection probability models were applied to the data. Based on the lowest AIC value the hazard-rate key function provided the most parsimonious fit with data divided into five equal intervals (Figure 1 ). None of the parameter adjustments improved the fit. The effective detection radius (EDR) was approximately $39 \mathrm{~m}$.

In the protected Amurum woodlands Rock Firefinches occurred at a mean density of 0.79 birds/ha but this was not significantly greater than the 0.55 birds/ha recorded in the unprotected surrounding area (Table 1 ). Coefficients of variation in the density estimates for Amurum and the surrounding habitat were $22.02 \%$ and $20.71 \%$ respectively, suggesting that these density estimates are robust (Buckland et al. 2001). The protected area at Amurum is approximately 90 ha. Extrapolation of the density estimate gives a population of 71 birds for this area (95\% CL $37-108$ birds). The unprotected area had no defined boundary so extrapolation is not possible.

\section{Habitat availability}

In total, 386 points were surveyed over two strata: 129 in Amurum and 257 in the surrounding unprotected habitats (Table 2). Habitat composition varied greatly

Table 1. Density estimates (birds/ha) and encounter rates (birds/point) for Rock Firefinches in the protected area at Amurum and in the unprotected surrounding area.

\begin{tabular}{lll}
\hline & Birds/ha (95\% CL) & Encounter rate (95\% CL) \\
\hline Amurum & $0.79(0.51-1.21)$ & $0.38(0.27-0.54)$ \\
Unprotected surrounding area & $0.55(0.37-0.82)$ & $0.26(0.19-0.36)$ \\
\hline
\end{tabular}


Table 2. Habitat availability in the Amurum reserve, the surrounding unprotected area, and in the study area overall.

\begin{tabular}{|c|c|c|c|c|c|c|}
\hline \multirow[t]{2}{*}{ Habitat } & \multicolumn{2}{|c|}{ Amurum woodlands $K=129$} & \multicolumn{2}{|c|}{ Surrounding area $K=257$} & \multicolumn{2}{|c|}{ Pooled $K=386$} \\
\hline & $n$ & $n / K$ & $n$ & $n / K$ & $n$ & $n / K$ \\
\hline Scrub & 68 & 0.53 & 66 & 0.26 & 134 & 0.35 \\
\hline Abandoned farmland & 1 & 0.01 & 89 & 0.35 & 90 & 0.23 \\
\hline Inselberg & 34 & 0.26 & 45 & 0.18 & 79 & 0.20 \\
\hline Farmland & 1 & 0.01 & 29 & 0.1 & 30 & 0.08 \\
\hline Riparian & 14 & 0.11 & 9 & 0.04 & 23 & 0.06 \\
\hline Rocky outcrop & 4 & 0.03 & 14 & 0.05 & 18 & 0.05 \\
\hline Grassland & o & o & 9 & 0.04 & 9 & 0.02 \\
\hline Gallery forest & 7 & 0.05 & o & o & 7 & 0.02 \\
\hline
\end{tabular}

$K$, total no. of points in area; $n$, no. of points in habitat; $n / K$, encounter rate.

between the two areas. In Amurum, the encounter rate (0.53) suggested that over half of the habitat was scrub. Inselbergs were encountered in roughly a quarter of the area (o.26). In contrast to Amurum, the unprotected surrounding area was dominated by abandoned farmland (0.35). Scrubland occurred at about a quarter of the points, with inselberg habitat representing less than a fifth. Active farmland occurred at about $10 \%$ of the points.

\section{Habitat associations}

The observed habitat associations of Rock Firefinches were the overall frequencies of the habitat types within which birds were actually seen during point-counts. For this analysis all Rock Firefinch observations in each habitat in Amurum and the surrounding unprotected area were therefore pooled. The expected habitat associations were derived from the frequencies of each habitat type recorded within the $15 \mathrm{~m}$ radius around each transect point, the habitat encounter rate. If there was no significant habitat choice, the number of Rock Firefinch sightings in each habitat would vary with the frequency of each habitat in the area overall. The expected number in each habitat was therefore calculated by dividing the total number of bird observations by the habitat encounter rate, and compared with the number actually observed in each habitat (Figure 2). The observed habitat associations of Rock Firefinches were significantly different from random $\left(\chi^{2} 7=252.61, P<0.01\right)$, reflecting an apparent strong association with inselberg and rocky outcrop habitats and a strong aversion to abandoned farmland, where no observations were made despite the high occurrence of this habitat on transects. There is a distinct avoidance of scrub and no firefinches were seen in riparian, grassland or gallery forest habitats. As the number of points in these last three habitats was low, however, it was not possible to make inferences on any negative associations. A GIS projection of the observed distribution of Rock Firefinches within the Amurum woodlands also clearly showed a strong positive association with inselberg habitat and avoidance of scrub (Figure 3). Although some firefinches were observed in scrub, all were close to inselbergs.

\section{Discussion}

Rock Firefinch shows a strong positive association with inselbergs and rocky outcrops. Indeed, practically all observations away from inselbergs were made very close to 


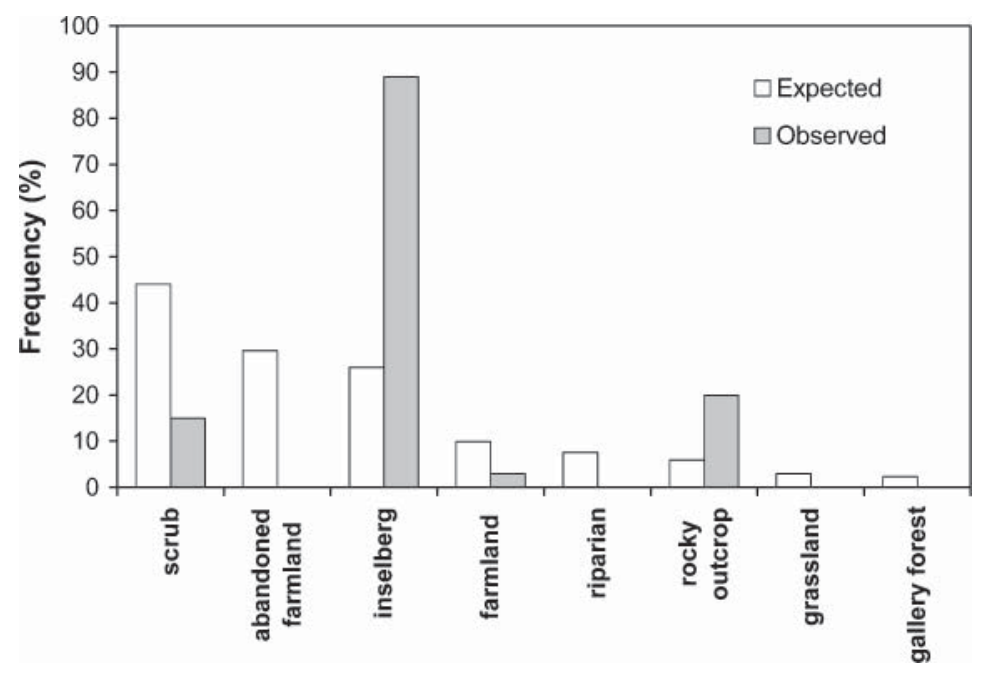

Figure 2. Observed and expected habitat associations of Rock Firefinches on the Jos Plateau.

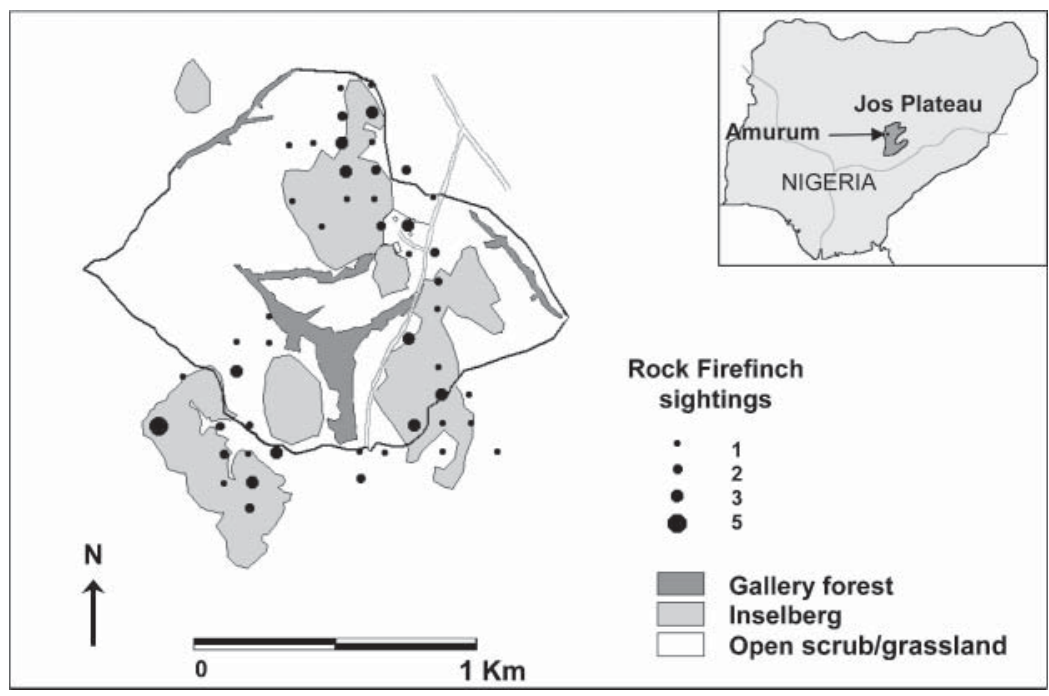

Figure 3. Distribution of Rock Firefinch in the Amurum reserve. The white area within the Amurum boundary is characterized by bushy and grassy scrubland with occasional small rocky outcrops. The area outside the boundary is dominated by both cultivated and abandoned farmland, interspersed with areas of scrub and small rocky outcrops. Inset: Nigeria showing the location of the Jos Plateau and Amurum.

them. Although estimated firefinch densities within Amurum were approximately $25 \%$ higher (though not significantly so) than in the surrounding unprotected habitat, the occurrence of inselberg and rocky outcrop habitat was also around $25 \%$ higher. 
Although these habitats remain relatively undamaged in remote areas where access is difficult, in other areas encroaching farmland and intensive wood-cutting for both domestic and commercial firewood could pose a threat. Inselbergs and rocky outcrops occur across the whole of the Jos Plateau and even those isolated among extensive areas of farmland and scrub were found still to support Rock Firefinches, but it is unknown to what extent the birds may disperse across intervening poorer habitat. If the species is highly sedentary, encroaching human occupation and habitat degradation could result in further isolation in small areas.

Because of their restricted ranges, it has been suggested that both Rock Firefinch and its brood parasite, Jos Plateau Indigobird, should be recognized as Near Threatened species and their habitat protected (Collar et al. 1994). This study has shown, however, that although Rock Firefinches are locally abundant around protected inselberg habitat ( $0.79 \mathrm{birds} / \mathrm{ha})$, they are not significantly less so in the surrounding unprotected area ( 0.55 birds/ha) that is typical of the Jos Plateau ecoregion, provided this also contains rocky habitat. This density is not significantly different from that of Red-billed Firefinches Lagonosticta senegala in the unprotected farmed area surrounding Amurum (0.38 birds/ha, 95\% CL 0.21-0.70 birds/ha; Wright 2002 and unpublished). Red-billed Firefinch is the commonest and most widespread firefinch in West Africa (Borrow and Demey 2001), and in this study appeared to be strongly associated with farmland and avoided inselbergs. Red-billed Firefinches were too seldom encountered on surveys within the protected area at Amurum for a reliable estimate to be obtained from distance sampling but clearly occur there at significantly lower density (0.10 birds/ha, 95\% CL 0.03-0.36; Wright 2002 and unpublished).

Density estimates are not available for Jos Plateau Indigobird, though earlier studies of Red-billed Firefinch have shown that it is Io times more abundant than its indigobird (Payne and Payne 1994). The same may hold true for Jos Plateau Indigobird, about which little is known. During fieldwork, no indigobirds of any species were seen until late June, suggesting that they may be intra-African migrants that return to the Plateau area during the rains to breed. If they are migrants, their destination when they leave the Plateau is not known.

\section{Acknowledgements}

This study would not have been possible without the generous logistical support of Tasso Leventis and Phil Hall of the Nigerian Conservation Foundation (NCF), financial assistance from the University of Edinburgh Development Trust and support from the staff of the A. P. Leventis Ornithological Research Institute (APLORI). Ross McGregor was an excellent source of advice and Jeremy Linsdell kindly provided GIS projections of Amurum. This paper is APLORI publication no.12.

\section{References}

Bibby, C. J., Burgess, N. D., Hill, D. A. and Mustoe, S. H. (2000) Bird census techniques. London: Academic Press.

Borrow, N. and Demey, R. (2001) Birds of western Africa. London: Christopher Helm.

Buckland, S. T., Anderson, D. R., Burnham, K. P., Laake, J. L., Borchers, D. L. and Thomas, L. (2001) Introduction to distance sampling: estimating abundance of biological populations. Oxford: Oxford University Press.

Collar, N. J., Crosby, M. J. and Stattersfield, M. J. (1994) Birds to watch 2. The world list of threatened birds. BirdLife Conservation Series No. 4. Cambridge, U.K.: BirdLife International. 
Ezealor, A. (2001) Nigeria. Pp. 673-682 in L. D. C. Fishpool and M. I. Evans, eds. Important Bird Areas in Africa and associated islands: priority sites for conservation. BirdLife Conservation Series No. 11. Newbury, U.K.: Pisces Publications.

Fishpool, L. D. C. and Evans, M. I. (2001) Important Bird Areas in Africa and associated islands. Newbury and Cambridge, U.K.: Pisces Publications and BirdLife International.

Fry, C. H. and Keith, S. (2004) The birds of Africa. Volume 7. London: Christopher Helm.

Hadejia, I. A, Mohammed, Z., Inahoro, I., Buhari, M. and Olapojoye, S. A. (2000) Participatory assessment of natural resources and traditional management practices in Laminga Community Amurum forest, near Jos, Plateau State. NCF unpublished report. Lagos: Nigerian Conservation Foundation.

Lodewijk, J. and Were, R. (2001) Jos Plateau Forest-Grassland Mosaic (AT1010). http:// www.worldwildlife.org/wildworld/profiles/terrestrial/at/atıoı_full.html

Payne, R. B. (1994) Brood parasitism in Nigerian birds. Pp. 53-56 in J. H. Elgood, J. B. Heigham, A. M. Moore, A. M. Nason, R. E. Sharland and N. J. Skinner, eds. The birds of Nigeria: an annotated checklist. BOU Check-List No.4 (2nd edition). Tring: British Ornithologists' Union.

Payne, R. B. (1996) Field identification of the indigobirds. Bull. Afr. Bird Club 3: 14-25.

Payne, R. B. (1998) A new species of firefinch Lagonosticta from northern Nigeria and its association with the Jos Plateau Indigobird Vidua maryae. Ibis 140: 368-381.

Payne, R. B. and Payne, L. L. (1994) Song mimicry and species status of the indigobirds, Vidua: associations with Quail-finch, Ortygospiza atricollis, Goldbreast, Amandava subflava and Brown Twinspot Clytospiza monteiri. Ibis 136: 291-304.

Reynolds, R. T., Scott, J. M. and Nussbaum, R. A. (1980) A variable circular-plot method for estimating bird numbers. Condor 82: 309-313.

Scott, J. M. and Ramsey, F. L. (1981) Length of count period as a possible source of bias in estimating bird densities. Studies Avian Biol. 6: 409-413.

Thomas, L., Laake, J. L., Derry, J. F., Buckland, S. T., Borchers, D. L., Anderson, D. R., Burnham, K. P., Strindberg, S., Hedley, S. L., Burt, M. L., Marques, F., Pollard, J. H. and Fewster, R. M. (1998) Distance 3.5. Research Unit for Wildlife Population Assessment, University of St Andrews.

White, F. (1983) The vegetation of Africa, a descriptive memoir to accompany the UNESCO/ AETFAT/UNSO vegetation map of Africa (3 plates, Northwestern Africa, Northeastern Africa and Southern Africa, 1:5,000,00o). Paris: UNESCO.

Wright, D. J. (2002) Population densities and habitat associations of the range-restricted Rock Firefinch, Lagonosticta sanguinodorsalis, and other firefinches from the Jos Plateau, Nigeria. Unpublished MSc thesis, University of Edinburgh.

WWF (1998) A conservation assessment of terrestrial ecoregions of Africa: draft proceedings of a workshop, Cape Town, South Africa, August 1998. Washington, D.C.: World Wildlife Fund.

DAVID WRIGHT

A. P. Leventis Ornithological Research Institute, University of Jos, P. O. Box 13404, Jos, Plateau State, Nigeria.

Institute of Evolutionary Biology, University of Edinburgh, King's Buildings, Edinburgh EHg 3JT, Scotland, UK.

PETER JONES*

Institute of Evolutionary Biology, University of Edinburgh, King's Buildings, Edinburgh EH9 3JT, Scotland, UK.

*Author for correspondence (e-mail: peter.jones@ed.ac.uk) 